to see any suggestive resemblance even in the gross appearance of the spikelets, or in the size, color, shape or texture of their glumes. But were they alike in all these particulars there are certain technical differences which at once separate them generically. E. pilifera is a true Eragrostis, of the section Eueragrostis, and its generic characters are strongly marked. The points separating Eragrostis from Molinia may thus be presented :

\begin{tabular}{l|l}
\multicolumn{1}{c|}{$\begin{array}{l}\text { Eragrostis: } \\
\text { Rachilla continuous. } \\
\begin{array}{l}\text { Flowering glumes 3-nerved, cadu- } \\
\text { cous; palea persistent. }\end{array}\end{array}$} & $\begin{array}{l}\text { Molin: } \\
\text { Rachilla articulate. }\end{array}$ \\
Hilum punctiform. & $\begin{array}{l}\text { Flowering glumes 5-nerved, falling } \\
\text { off with the palea. } \\
\text { Hilum elongated linear. }\end{array}$
\end{tabular}

Molinia is certainly related to Eragrostis and, according to the latest classification, stands next to it following Disanthelium, but the characters separating it are well marked and of such a nature as to exclude it entirely. To open Eragrostis - a genus already overburdened with species and therefore characterized with difficulty-to admit Molinia would be to destroy it.-F. Lamson Scribner, Knoxville, Tenn.

\title{
Freaks of roses.
}

An article in the September GazeTte on "Freaks of roses," calls to mind a modification of a rose observed in a cernetery at Cape Girardeau, Mo., about a year ago. The stamens were mostly converted into petals, but the pistils were modified in a curious manner. Some had become leaves similar to those growing on the branches, while in others, half of the carpel was like half of a leaf, the other half remaining carpel-like, being curved inward and having a row of ovules on its margin. Still others had the upper half of the carpel altered to a leaf-like form, the lower half remaining like so much of a true pistil.-W.J. SpILlman, Vincennes, Ind.

\section{CURRENT LITERATURE.}

\section{Scientific Papers of Asa Gray. ${ }^{1}$}

These Handsome volumes form a worthy memorial of Dr Gray. The wealth of material has made Professor Sargent's task a difficult one, but it is hard to see how he could have done better. To those of us who loved this side of our great botanist these volumes are especially welcome. The nature of the man could not be expressed in the dry details of systematic work; but in his reviews, biographical sketches and essays the bright, genial master found free expression, and his keen but always kind criticism reveals much of the secret of his hold upon American botanists. The present volumes do not include the miscellaneous papers already collected by him in Darwiniana, or his systematic papers, but the remnant gives $\mathrm{u}$ 800 pages of delightful reading, really furnishing " the best account of the

1SARgent, Charles Sprague.-Scientific papers of Asa Gray, selected. Vol. I. Reviews of works on botany and related subjeots (i834-1887), pp. viii. 397. Vol. II. Essays; Biographical sketches (1841-1886), pp. iv. 503. Houghton, Mifflin and Company, Boston and New York, 1889. 